\title{
MEDIASI CITY BRANDING PADA PENGARUH KESADARAN MEREK, ASOSIASI MEREK, DAN KESAN KUALITAS TERHADAP KEPUTUSAN MEMILIH PERGURUAN TINGGI NEGERI DI SURABAYA
}

\author{
Ria Astuti Andrayani \\ Jurusan Manajemen, Fakultas Ekonomi, Universitas Negeri Surabaya \\ e-mail: riaandrayani@gmail.com \\ Sri Setyo Iriani \\ Jurusan Manajemen, Fakultas Ekonomi, Universitas Negeri Surabaya \\ e-mail: srisetyo2009@gmail.com
}

\begin{abstract}
Education is a major concern of government in enhancing and improving the quality of human resources. Indonesia have stratified formal education which higher education contains of state university and private university. Surabaya is a city in Indonesia which has the largest public universities. There are four universities, there are universitas airlangga (UA), universitas negeri Surabaya (Unesa), institut teknologi sepuluh nopember (ITS), and IAIN sunan ampel. This study aims to test and analyze whether brand awareness, brand association, and perceived quality affect decision to choose state universities in Surabaya. This type of this research is quantitative, using multistage sampling with 377 respondents. Statistical analysis that used is the approach of mutiple linear regression which tested to every object. The results of this study showed that brand awareness and perceived quality has a positive influence on the decision to choose state universities in Surabaya. there are differences in the effect of brand association that the UA and Unesa positive influence while at IAIN Sunan Ampel, ITS and negative effect. Those influences has different athmosphere by respondent of Surabaya 's city branding. There's not all of the respondent to consider city branding of Surabaya when they choose to study at Surabaya.
\end{abstract}

Keywords: brand awareness, brand association, perceived quality, decision to choose, state university 


\section{PENDAHULUAN}

\section{Latar belakang}

Pembangunan bangsa harus memperkokoh pilar-pilar pendidikan yang merupakan satu upaya pemerintah meningkatkan human development index (HDI) (Wijaya, 2008) yang salah satunya melalui peningkatan kualitas layanan di dunia pendidikan. Pendidikan adalah usaha sadar dan terencana untuk mewujudkan suasana belajar dan proses pembelajaran atau penelitian agar peserta didik secara aktif dapat mengembangkan potensi dirinya supaya memiliki kekuatan spiritual keagamaan, emosional, pengendalian diri, kepribadian, kecerdasan, akhlak mulia, serta keterampilan yang diperlukan dirinya dan masyarakat (Juanda, 2010). Di Indonesia, upaya pembangunan pendidikan formal dilakukan di berbagai jenjang, mulai pendidikan dasar, menengah sampai pendidikan tinggi (Alma, 2008: 104). Sehingga perguruan tinggi negeri maupun swasta semakin bersaing dalam meningkatkan kualitas layananya.

Dengan melihat jumlah PTN yang terus bertumbuh maka masyarakat memiliki kesempatan lebih besar dalam memilih. Jumlah perguruan tinggi di Indonesia pada tahun $2009-2010$ mengalami peningkatan sebesar 0,5\% (dikti, 2010). Jawa Timur memiliki 9 PTN yang ada di Surabaya saja terdapat 4 PTN yaitu UA, Unesa, ITS, IAIN Sunan Ampel dan yang lain tersebar di Malang, Jember, dan Madura (Snmptn, 2013).

Fenomena ini menuntut perguruan tinggi membangun ekuitas merek yang kuat dibenak masyarakat (Ali-Choudhury dalam Chapleo,2010). Terlebih lagi peran besar suatu merek sesungguhnya merupakan suatu akibat dari nilai suatu merek itu sendiri. Menurut Aaker (1997:23) ekuitas merek juga bisa mempengaruhi rasa percaya diri konsumen dalam mengambil keputusan pembelian (baik itu karena pengalaman masa lalu dalam menggunakannya maupun kedekatan dengan merek dan aneka karakteristiknya).

Dalam membangun ekuitas merek perguruan tinggi terdapat 5 aset penting yaitu loyalitas merek (brand loyalty), kesadaran nama (brand name), kesan kualitas (perceived quality), asosiasi-asosiasi merek sebagai tambahan terhadap kesan merek, dan aset-aset merek lainnya (Aaker, 1997:23). Namun dalam keputusan memilih perguruan tinggi mahasiswa mempertimbangkan kesadaran merek, asosasi merek, dan kesan kualitas. Hal ini mendasari peneliti untuk menggunakan judul "pengaruh kesadaran merek, asosiasi merek, dan kesan kualitas terhadap keputusan memilih perguruan tinggi negeri di Surabaya".

Merek perguruan tinggi tidak lain juga harus mendukung suatu city branding atau konsep sebuah kota, dalam hal ini city branding kota Surabaya. Kota Surabaya merupakan kota terbesar kedua di Indonesia yang memiliki berbagai fasilitas serta sangat mempengaruhi pertumbuhan ekonomi negara. Surabaya memiliki berbagai kawasan industri yang membuat pertumbuhan ekonomi Surabaya naik sebesar 6\% walaupun dalam masa krisis tahun 2009 . Hal tersebut yang sering menjadikan alasan calon mahasiswa dari luar Surabaya mempertimbangkan untuk berkuliah di Surabaya disamping banyaknya perguruan tinggi yang terdapat di Surabaya.

\section{Rumusan Masalah}

1. Apakah kesadaran merek, asosiasi merek, dan kesan kualitas berpengaruh terhadap keputusan memilih PTN di Surabaya? 
2. Apakah city branding dapat memediasi pengaruh kesadaran merek, asosiasi merek, dan kesan kualitas dalam mempengaruhi keputusan memilih PTN di Surabaya?

\section{Tujuan Penelitian}

Untuk menganalisis dan membahas mediasi city branding pada kesadaran merek, asosiasi merek, dan kesan kualitas dalam mempengaruhi keputusan memilih PTN di Surabaya.

\section{LANDASAN TEORI}

\section{Kerangka teoritis}

Jasa Pendidikan

Jasa pendidikan memiliki hubungan timbal balik dengan lingkungannya terlebih lagi pada kualitas layanan pendidikannya (Wijaya 2008). Hal tersebut mengindikasikan kompleksitas yang mengharuskan jasa pendidikan mengembangkan hubungan dengan stakeholder secara berkelanjutan (Moogan 2010). Dari sudut pandang manajemen mutu, perguruan tinggi perlu mengendalikan setiap tahapan bisnisnya mulai input, proses, output, dan kepuasan stakeholder (Alma, 2008:75). Tujuannya agar perguruan tinggi dapat mengelola sumber daya secara optimal untuk menjamin mutu layanan akademik bagi mahasiswa dan menjamin akuntabilitas terhadap stakeholder. Agar perguruan tinggi dapat menarik dan membentuk citra baik terhadap publik maka perlu adanya dosen bermutu dan mutu akademik yang dapat dibanggakan (Alma, 2008:22-29).

City Branding Surabaya

Merupakan suatu pencitraan kota yang memiliki karakteristik khusus yang dapat dijelaskan, diidentifikasikan, dan berkeberlanjutan/sustainable (Magnadi dan Indriani: 2011). Pentingnya city branding adalah agar sebuah kota benar-benar dapat dibedakan dari daerah lain sebagai salah satu strategi meraih keunggulan bersaing baik tingkat lokal, regional, bahkan internasional. Surabaya merupakan ibu kota dari Jatim dan menjadi kota terbesar kedua di Indonesia. Kini, Surabaya telah memiliki penghargaan sebagai kota yang memiliki konsistensi pertumbuhan ekonomi peringkat ke-6 tahun 2009 di Asia. Secara umum proses collaboration marketing management dalam penentuan city branding diarahkan pada 3 potensi daerah yaitu investasi dengan kelompok sasaran para investor, pariwisata dengan kelompok turis domestik maupun mancanegara, dan perdagangan dengan kelompok sasaran trader. City Branding yang dimiliki Surabaya adalah Sister City yang kini telah memilliki mitra kerjasama bahkan dengan negara lain di anatranya adalah Seattle (USA), Busan (Korea), Kochi dan Kitakyushu (Jepang), Marseille (Prancis), Guangzhou dan Xiamen (China), dsb (Surabaya, 2011).

\section{Kesadaran Merek}

Kesadaran merek adalah kesanggupan seorang calon pembeli untuk mengenali atau mengingat kembali bahwa suatu merek merupakan bagian dari kategori produk tertentu (Aaker, 1997:90). Empat tingkat kesadaran merek dari tingkat tertinggi hingga tingkat terendah menurut Aaker (1997:92) yaitu Top of mind (puncak pikiran), Brand recall (pengingatan kembali terhadap merek), Brand recognition (pengenalan merek), dan Unaware of brand (tidak menyadari merek). Sehingga pengukuran kesadaran merek dalam penelitian 
ini mengadaptasi dari Aaker (1997:92) dengan adaptasi pernyataan penelitian So et al (2010), Wang et al (2008).

Asosiasi Merek

Sebuah merek adalah seperangkat asosiasi, biasanya terangkai dalam berbagai bentuk yang bermakna. Asosiasi dan pencitraan keduanya mewakili berbagai persepsi yang menunjukkan suatu kesan tertentu dalam kaitannya dengan memori terhadap sebuah merek. (Rahman 2008; Aaker 1997: 160; Tjiptono 2005:40). Sehingga pengukuran asosiasi merek dalam penelitian ini mengadaptasi pengukuran Keller (2003:70), Keller dalam Paramosa (2012), dan Alma (2008:29).

\section{Kesan Kualitas}

Kesan kualitas dapat didefinisikan sebagai elemen kritis yang terdapat pada persepsi pelanggan terhadap perbandingan alternative keseluruhan kualitas atau keunggulan suatu produk atau jasa layanan untuk pembuatan keputusan pelanggan (Aaker 1997:124; Yee et al 2011). Adapun pengukuran kesan kualitas menurut Parasuraman yaitu reliability, tangible, responsiveness, assurance, dan emphaty. Sehingga pengukuran dalam penelitian ini menggunakan dimensi kualitas layanan Parasuraman (dalam Lovelock, 2007:98), Parasuraman (dalam Lupiyoadi, 2008:182), Parasuraman (dalam angell et al, 2008), dan Alma (2005:46).

\section{Keputusan Memilih}

Pengambilan keputusan konsumen adalah bagian utama dari perilaku konsumen, tetapi cara kita mengevaluasi dan memilih produk (dan jumlah pemikiran kita dimasukkan ke dalam pilihan) memiliki banyak variasi, tergantung pada beberapa dimensi seperti tingkat kebaruan atau risiko dalam keputusan (Solomon, 2013:319). Pengukuran keputusan memilih dapat mengadaptasi dari dimensi keputusan pembelian model perilaku konsumen Kotler dan Keller (2009:240) yaitu pilihan produk, pilihan merek, pilihan dealer, jumlah pembelian, waktu pembelian, dan metode pembayaran. Sehingga dalam penelitian ini pengukuran keputusan memilih perguruan tinggi mengadaptasi dimensi keputusan pembelian Kotler dan Keller (2009:240) dan mengadaptasi pengukuran item pernyataan dari Kotler dan Armstrong (dalam Zulfikar, 2012) yaitu pilihan jurusan, pilihan perguruan tinggi, dan pilihan jalur.

Hubungan Kesadaran Merek Terhadap Keputusan Memilih

Kepentingan pengingatan merek karena merupakan suatu pengukuran "mind-share" konsumen atau puncak pikiran kesadaran dari produk/jasa. Tanpa adanya "mind-share" perguruan tinggi tidak dapat membangun merek yang kuat (ekuitas merek) (Pinar et al: 2012). Sehingga kepentingan ekuitas merek dalam keputusan memilih PTN dipengaruhi rasa percaya diri (Aaker, 1997:23). Disamping itu reputasi PT dalam memprediksi kesadaran merek, digunakan sebagai acuan menilai suatu PT atau merek PT untuk membuat keputusan memilih (Brewer dan Zhao, 2010).

Hubungan Asosiasi Merek Terhadap Keputusan Memilih

Asosiasi dan pencitraan keduanya mewakili berbagai persepsi yang mungkin mencerminkan suatu merek (Aaker, 1997: 161). Asosiasi positif konsumen dapat menimbulkan penerimaan, rasa suka bahkan minat yang akan mempengaruhi keputusan pembelian (Ergin et al, 2006). 
Namun pengaruh yang diberikan dapat bervariatif tergantung pada kekuatan asosiasi merek itu sendiri dibenak konsumen. Hal tersebut mengingat salah satu karakteristik jasa adalah bervariatif.

\section{Hubungan Kesan Kualitas Terhadap Keputusan Memilih}

Kesan kualitas didefinisikan sebagai persepsi konsumen tentang keseluruhan kualitas dari sebuah produk atau merek dengan alternative relative yang dimiliki bahkan merupakan sebuah asosiasi terhadap status dari masing-masing dimensi ekuitas merek (Pinar et al 2012). Pada sebuah penelitian menunjukkan ketika membuat keputusan memilih PT yang sangat beresiko dan meragukan, "siswa akan cenderung melihat kualitas layanan yang telah terbukti", yang dapat menjadi suatu kepentingan dalam membuktikan fungsi dari PT (Angell, 2008). Kesan perguruan tinggi di benak konsumen dapat berbagai variasi pengaruhnya terhadap keputusan memilih PT.

\section{Hipotesis}

Hipotesis dalam penelitian ini adalah:

H1: Terdapat berpengaruh positif kesadaran merek, asosiasi merek, dan kesan kualitas terhadap keputusan memilih perguruan tinggi negeri di Surabaya.

$\mathrm{H} 2$ : Terdapat pengaruh city branding dalam memediasi pengaruh kesadaran merek, asosiasi merek, dan kesan kualitas dalam mempengaruhi keputusan memilih perguruan tinggi negeri di Surabaya

\section{METODE PENELITIAN}

\section{Metode Seleksi dan Pengumpulan Data}

Penelitian ini menggunakan pendekatan kuantitatif dan kualitatif. Metode kuantitatif digunakan dalam membuktikan dan menjelaskan pengaruh kesadaran merek (X1), asosiasi merek (X2), dan kesan kualitas (X3) terhadap keputusan memilih (Y). Metode kualitatif akan digunakan dalam membuktikan dan menjelaskan pengaruh city branding (Z) dalam memediasi kesadaran merek (X1), asosiasi merek (X2), dan kesan kualitas (X3) terhadap keputusan memilih (Y) perguruan tinggi negeri di Surabaya.

Metode pengumpulan data melalui penyebaran angket dan wawancara / depth interview pada mahasiswa angkatan 2012 di keempat PTN di Surabaya (UA, Unesa, ITS, IAIN Sunan Ampel). Angket dibuat dengan skala $1-4$ dengan metode rating scale. Sampel dalam penelitian ini berjumlah 396 responden menggunakan multistage sampling. Adapun tahapannya dengan membagi sampel secara presisi (Malhotra, 2009:379) dengan menggunakan rumus pada teknik cluster sampling (Malhotra, 2009: 385) pada keempat obyek sampel. Kemudian sampel dipilih secara acak sesuai dengan kriteria yang telah ditentukan (purposive) yaitu pada saat pembagian angket merupakan mahasiswa pada PTN yang dikunjungi dan merupakan mahasiswa tahun pertama. Selanjutnya pada praktik pengambilan sampel peneliti akan membagikan angket pada siapapun yang ditemui (accidental) sesuai dengan ketentuan. Berikut proporsi sampel pada keempat obyek penelitian: 


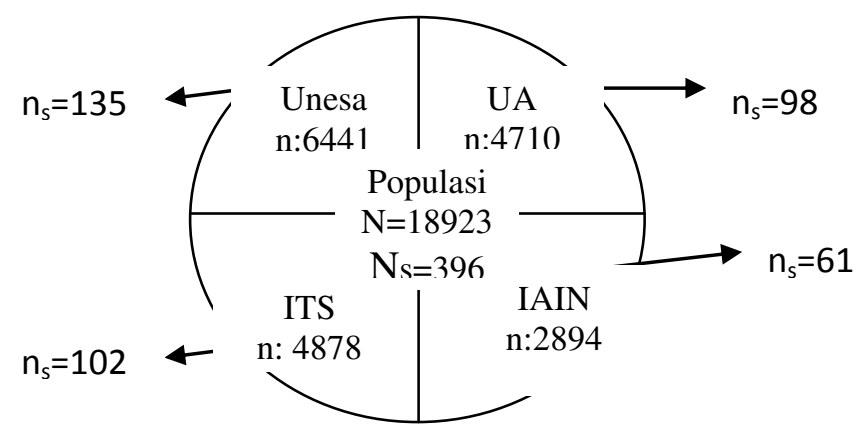

Gambar 1: Proporsi sampel di setiap perguruan tinggi

\section{Definisi Operasional Variabel dan Pengukuran}

Kuantitatif

Angket yang diberikan pada responden merupakan angket dengan pernyataan tertutup dan terbuka. Pertanyaan tertutup responden diminta memilih jawaban yang disediakan berdasarkan instrumen yang telah ditetapkan (sangat tidak setuju, tidak setuju, setuju, dan sangat setuju).

Tabel 1: Pengukuran indikator pertanyaan tertutup

\begin{tabular}{|c|c|c|c|c|c|}
\hline Variabel & DOV & Indikator & Pernyataan & \multicolumn{2}{|c|}{ Referensi } \\
\hline \multirow[t]{6}{*}{$\begin{array}{l}\text { Kesadaran } \\
\text { Merek }\end{array}$} & \multirow{6}{*}{$\begin{array}{c}\text { kesanggupan } \\
\text { mahasiswa } \\
\text { untuk } \\
\text { mengenali } \\
\text { atau } \\
\text { mengingat } \\
\text { kembali } \\
\text { PTN }\end{array}$} & \multirow[t]{2}{*}{$\begin{array}{c}\text { Recognition } \\
\text { Brand }\end{array}$} & $\begin{array}{l}\text { Saya sadar adanya PTN di } \\
\text { Surabaya }\end{array}$ & \multirow{6}{*}{$\begin{array}{l}\text { Aaker } \\
(1997: 9 \\
2)\end{array}$} & $\begin{array}{l}\text { So et al } \\
(2010)\end{array}$ \\
\hline & & & $\begin{array}{l}\text { Saya dapat mengenali } \\
\text { PTN di Surabaya }\end{array}$ & & $\begin{array}{l}\text { So et al } \\
(2010)\end{array}$ \\
\hline & & \multirow[t]{3}{*}{$\begin{array}{l}\text { Brand } \\
\text { Recall }\end{array}$} & $\begin{array}{l}\text { PTN di Surabaya ada } \\
\text { dalam ingatan saya }\end{array}$ & & $\begin{array}{l}\text { So et al } \\
(2010)\end{array}$ \\
\hline & & & $\begin{array}{l}\text { Saya dapat } \\
\text { menggambarkan PTN di } \\
\text { Surabaya }\end{array}$ & & $\begin{array}{l}\text { So et al } \\
\text { (2010) }\end{array}$ \\
\hline & & & Saya tahu PTN di Surabaya & & $\begin{array}{l}\text { So et al } \\
(2010)\end{array}$ \\
\hline & & Top of mind & $\begin{array}{l}\text { PTN di Surabaya sangat } \\
\text { terkenal }\end{array}$ & & $\begin{array}{l}\text { Wang et } \\
\text { al (2008) }\end{array}$ \\
\hline \multirow[t]{4}{*}{$\begin{array}{l}\text { Asosiasi } \\
\text { merek }\end{array}$} & \multirow{4}{*}{$\begin{array}{c}\text { Kesuksesan } \\
\text { alumni dalam } \\
\text { pekerjaan dan } \\
\text { dalam } \\
\text { menghadapi } \\
\text { ujian di } \\
\text { masyarakat } \\
\text { menimbulkan } \\
\text { asosiasi } \\
\text { positif PT di } \\
\text { benak } \\
\text { masyarakat }\end{array}$} & $\begin{array}{c}\text { Kekuatan } \\
\text { merek }\end{array}$ & $\begin{array}{l}\text { Saya sangat familiar } \\
\text { dengan PTN di Surabaya }\end{array}$ & \multirow{4}{*}{$\begin{array}{l}\text { Keller } \\
(2003: 7 \\
0)\end{array}$} & $\begin{array}{l}\text { Paramos } \\
\mathrm{a}(2012)\end{array}$ \\
\hline & & \multirow[t]{2}{*}{$\begin{array}{l}\text { Kesukaan } \\
\text { merek }\end{array}$} & $\begin{array}{l}\text { Alumni PTN di Surabaya } \\
\text { sukses di lapangan kerja }\end{array}$ & & $\begin{array}{l}\text { Alma } \\
(2008: 29 \\
)\end{array}$ \\
\hline & & & $\begin{array}{l}\text { Mahasiswa PTN di } \\
\text { Surabaya sukses di } \\
\text { lingkungan masyarakat. }\end{array}$ & & $\begin{array}{l}\text { Alma } \\
(2008: 29 \\
\text { ) }\end{array}$ \\
\hline & & $\begin{array}{c}\text { Keunikan } \\
\text { merek }\end{array}$ & $\begin{array}{l}\text { PTN di Surabaya memiliki } \\
\text { konsep yang unik }\end{array}$ & & $\begin{array}{l}\text { Paramos } \\
\text { a }(2012)\end{array}$ \\
\hline
\end{tabular}




\begin{tabular}{|c|c|c|c|c|c|}
\hline & $\begin{array}{c}\text { (Alma } \\
\text { 2008:29). }\end{array}$ & & & & \\
\hline \multirow[t]{15}{*}{$\begin{array}{l}\text { Kesan } \\
\text { kualitas }\end{array}$} & \multirow{15}{*}{$\begin{array}{c}\text { persepsi } \\
\text { mahasiswa } \\
\text { tentang } \\
\text { keseluruhan } \\
\text { kualitas } \\
\text { keempat PTN } \\
\text { di Surabaya } \\
\text { sebagai } \\
\text { alternatif } \\
\text { pilihan (Pinar } \\
\text { et al, 2012). } \\
\text { Kemenarikan } \\
\text { dan citra } \\
\text { positif PT } \\
\text { dibentuk } \\
\text { melalui dosen } \\
\text { yang bermutu } \\
\text { dan mutu } \\
\text { akademik } \\
\text { yang dapat } \\
\text { dibanggakan } \\
\text { (Alma, } \\
\text { 2008:22-29). }\end{array}$} & \multirow[t]{2}{*}{ Reliability } & $\begin{array}{l}\text { PTN di Surabaya memiliki } \\
\text { biaya pendidikan yang } \\
\text { sesuai dengan layanan } \\
\text { yang diberikan }\end{array}$ & \multirow{15}{*}{$\begin{array}{l}\text { Parasur } \\
\text { aman, } \\
\text { Berry, } \\
\text { dan } \\
\text { Zeitha } \\
\text { ml } \\
\text { (1991) }\end{array}$} & \multirow[t]{3}{*}{$\begin{array}{l}\text { Angell et } \\
\text { al, } 2008\end{array}$} \\
\hline & & & $\begin{array}{l}\text { PTN di Surabaya sangat } \\
\text { nyaman }\end{array}$ & & \\
\hline & & \multirow[t]{8}{*}{ Tangible } & $\begin{array}{l}\text { PTN di Surabaya memiliki } \\
\text { layout dan desain gedung } \\
\text { kampus yang menarik }\end{array}$ & & \\
\hline & & & $\begin{array}{l}\text { PTN di Surabaya memiliki } \\
\text { ruang kelas yang bersih }\end{array}$ & & $\begin{array}{l}\text { Lupiyoa } \\
\text { di } \\
(2008: 18 \\
\text { 2) }\end{array}$ \\
\hline & & & $\begin{array}{l}\text { PTN di Surabaya memiliki } \\
\text { gedung olahraga yang } \\
\text { bagus }\end{array}$ & & \multirow[t]{5}{*}{$\begin{array}{l}\text { Angell et } \\
\text { al, } 2008\end{array}$} \\
\hline & & & $\begin{array}{l}\text { PTN di Surabaya memiliki } \\
\text { laboratorium komputer } \\
\text { yang bagus }\end{array}$ & & \\
\hline & & & $\begin{array}{l}\text { PTN di Surabaya memiliki } \\
\text { kantin dan taman yang asri }\end{array}$ & & \\
\hline & & & $\begin{array}{l}\text { PTN di Surabaya memiliki } \\
\text { gedung perpustakaan yang } \\
\text { megah }\end{array}$ & & \\
\hline & & & $\begin{array}{l}\text { PTN di Surabaya memiliki } \\
\text { area belajar yang tenang }\end{array}$ & & \\
\hline & & & $\begin{array}{l}\text { PTN di Surabaya memiliki } \\
\text { karyawan dan dosen yang } \\
\text { ramah }\end{array}$ & & $\begin{array}{l}\text { Lovelock } \\
(2007: 98 \\
\text { ) } \\
\end{array}$ \\
\hline & & $\begin{array}{c}\text { Responsive- } \\
\text { ness }\end{array}$ & $\begin{array}{l}\text { PTN di Surabaya memiliki } \\
\text { akses yang cepat untuk } \\
\text { melayani mahasiswa }\end{array}$ & & $\begin{array}{l}\text { Angell et } \\
\text { al, 2008; } \\
\text { Lupiyoa } \\
\text { di, } \\
(2008: 18 \\
2)\end{array}$ \\
\hline & & \multirow[t]{4}{*}{ Assurance } & $\begin{array}{l}\text { PTN di Surabaya } \\
\text { mengutamakan tenaga ahli }\end{array}$ & & \multirow[t]{3}{*}{$\begin{array}{l}\text { Angell et } \\
\text { al, } 2008\end{array}$} \\
\hline & & & $\begin{array}{l}\text { PTN di Surabaya memiliki } \\
\text { pengajar yang ahli }\end{array}$ & & \\
\hline & & & $\begin{array}{l}\text { PTN di Surabaya memiliki } \\
\text { program yang bereputasi }\end{array}$ & & \\
\hline & & & $\begin{array}{l}\text { PTN di Surabaya memiliki } \\
\text { lokasi yang aman }\end{array}$ & & $\begin{array}{l}\text { Angell et } \\
\text { al, 2008; } \\
\text { Lupiyoa } \\
\text { di } \\
\text { (2008:18 }\end{array}$ \\
\hline
\end{tabular}




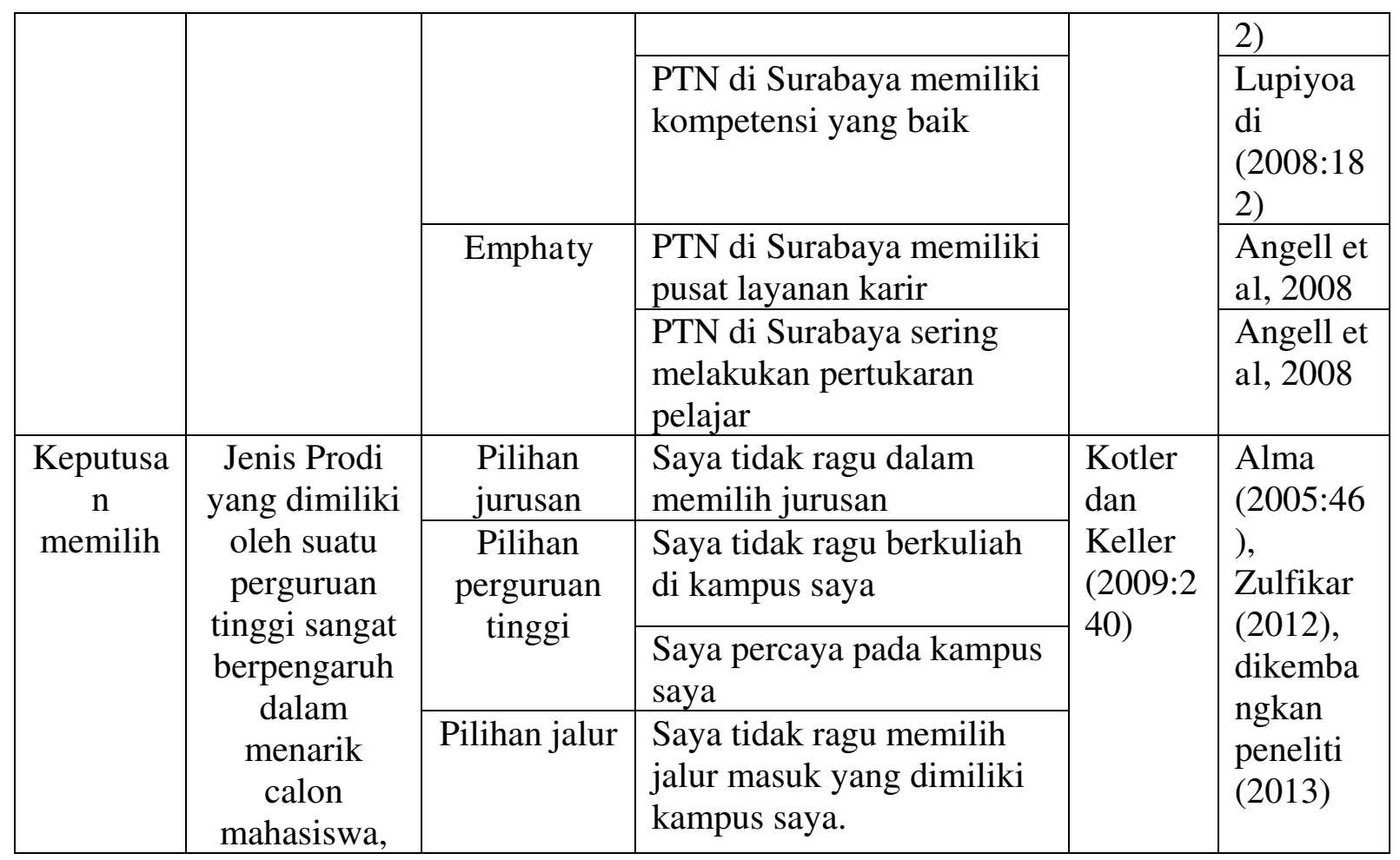

\section{Kualitatif}

Pengukuran kualitatif digunakan pada instrument pengukuran angket terbuka yang terkait $X 1$, $\mathrm{X} 2, \mathrm{X} 3, \mathrm{Y}$, dan $\mathrm{Z}$ yang selanjutnya ditabulasi dan dideskripsikan dalam mendukung pembahasan penelitian ini. Adapun kisi-kisi dan jawaban responden sebagai berikut:

Tabel 2: hasil pengukuran angket terbuka

\begin{tabular}{|c|c|c|c|c|}
\hline No & Variabel & Komponen & Pertanyaan & Jawaban \\
\hline 1 & $\mathrm{X} 1$ & Pengenalan & $\begin{array}{l}\text { PTN mana yang paling } \\
\text { Anda Kenali? }\end{array}$ & $\begin{array}{l}\text { Urutan Pilihan PTN (tabel } \\
\text { 5) }\end{array}$ \\
\hline 2 & $\mathrm{X} 2$ & Kepercayaan & $\begin{array}{l}\text { PTN apa yang paling } \\
\text { Anda percaya (dalam } \\
\text { memenuhi harapan } \\
\text { mahasiswa)? }\end{array}$ & $\begin{array}{l}\text { Urutan Pilihan PTN (tabel } \\
\text { 5) }\end{array}$ \\
\hline 3 & X3 & Kualitas & $\begin{array}{l}\text { PTN apa yang paling } \\
\text { berkualitas? }\end{array}$ & $\begin{array}{l}\text { Urutan Pilihan PTN (tabel } \\
\text { 5) }\end{array}$ \\
\hline 4 & $\begin{array}{l}\text { Y } \\
\text { (Pilihan } \\
\text { PTN) }\end{array}$ & Urutan Pilihan & $\begin{array}{l}\text { PTN apa yang } \\
\text { merupakan pilihan } \\
\text { pertama dan kedua Anda } \\
\text { untuk berkuliah? }\end{array}$ & $\begin{array}{l}\text { Pilihan Pertama dan Kedua } \\
\text { PTN di Surabaya (tabel 5) }\end{array}$ \\
\hline 5 & $\mathrm{Z}$ & Ibu kota & Peluang berkarya & $\begin{array}{l}\text { 'kalau saya belum sukses, } \\
\text { saya ga akan pulang" } \\
\text { "pada intinya saya ingin } \\
\text { kuliah di kota besar, } \\
\text { alhamdulillah saya diberi }\end{array}$ \\
\hline
\end{tabular}




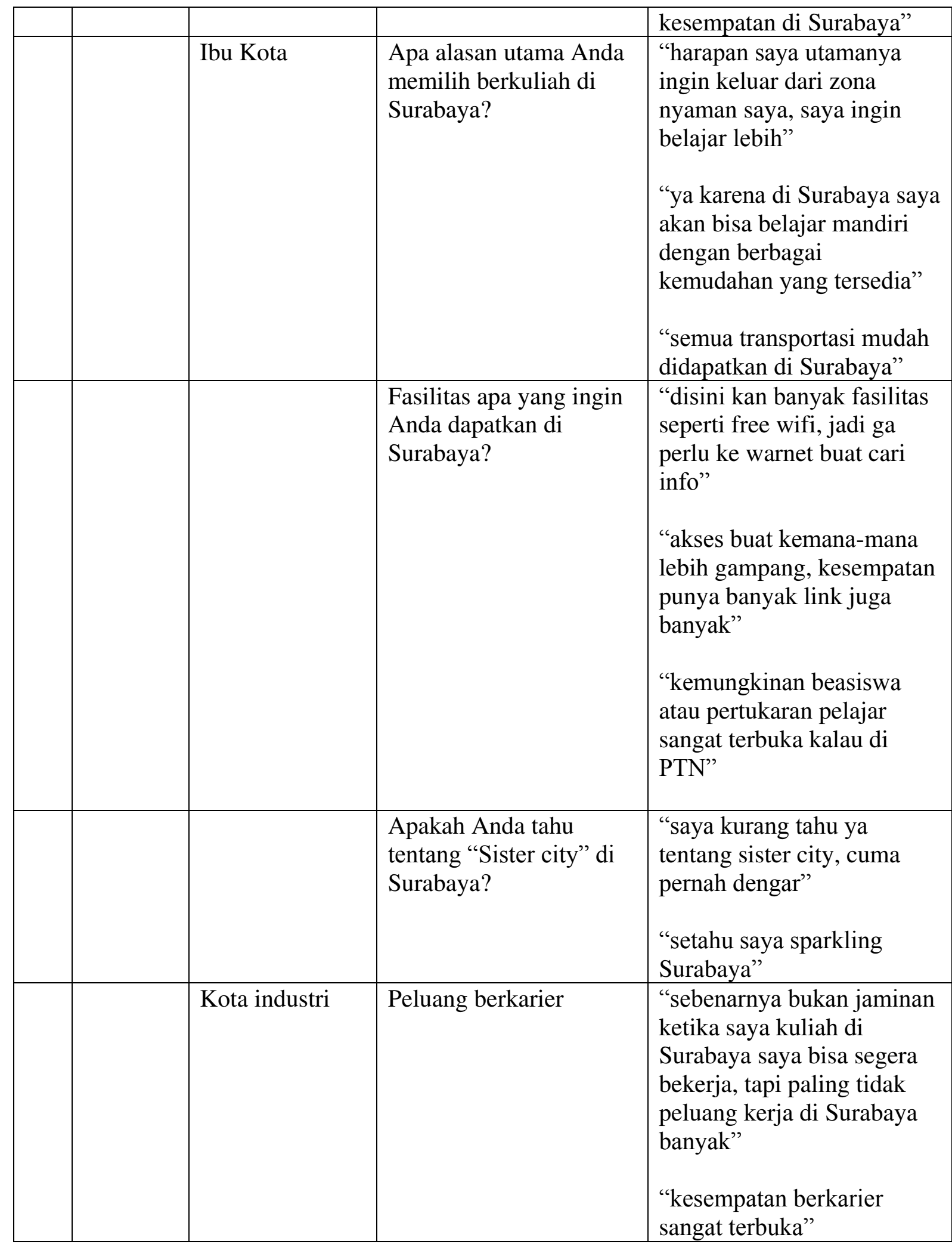

Sumber: jawaban responden, diolah peneliti

\section{Validitas, Reliabilitas, dan Uji Asumsi Klasik}

Dalam penelitian ini uji validitas menggunakan data dari angket yang telah diisi oleh 30 responden melalui satu kali proses validitas dengan menggunakan korelasi bivariasi terhadap 
skor total. Hasil pengujian menunjukkan bahwa masing-masing pernyataan bernilai 0,000 sehingga dapat disimpulkan valid karena tidak lebih dari 0,05 (Ghozali, 2012:55).Uji reliabilitas melalui dua kali pengujian dikarenakan ada salah satu yang tidak reliable yaitu pada variabel $Y$. Penyebabnya adalah adanya dua pernyataan pada indikator pilihan jalur tentang "memasuki jalur mandiri karena tidak lolos jalur nasional" dan "mendapat saran dari orang lain untuk menentukan jalur masuk PTN" yang ternyata lebih cocok digunakan dalam profil responden sehingga akan menunjukkan suatu karakteristik responden. hasil reliabilitas kedua menunjukkan bahwa nilai cronbach's Alpha lebih dari 0,70. Sehingga dapat disimpulkan bahwa variabel X1, X2, X3, dan Y reliable (Ghozali, 2012:48).

Tiga Uji Asumsi Klasik yang digunakan penellitian ini adalah uji normalitas, heteroskedastisitas, dan multikolinearitas. Hasil menunjukkan bahwa data dari keempat PTN adalah terdistribusi nomal dengan nilai signifikan lebih dari 0,5 ; terbebas dari heteroskedastisitas dengan hasil uji rank spearman lebih dari 0,05; dan nilai tolerance berada di atas 0,05 dan nilai VIF dibawah 10, sehingga dapat disimpulkan ketiga variabel bebas dari multikolinearitas.

\section{Metode Analisis Data}

Sesuai dengan tujuan penelitian ini yaitu untuk menganalisis pengaruh maka menggunakan analisis regresi (Santoso dan Tjiptono, 2004:195). Lebih lanjut analisis regresi berganda penelitian ini karena memiliki tiga variabel independen yaitu kesadaran merek, asosiasi merek, dan kesan kualitas serta satu variabel dependen yaitu keputusan memilih perguruan tinggi (santoso, 2004:324). Sehingga untuk menguji hipotesis dapat diketahui melalui uji t (uji parsial) dan koefisien determinasi untuk mengetahui kemampuan model regresi dalam menerangkan variasi variabel dependen (Ghazali, 2012:97).

\section{Tabel 3: hasil rekap pertanyaan terbuka}

\begin{tabular}{|c|c|c|c|c|c|c|c|c|c|c|c|c|c|c|c|c|}
\hline \multirow{3}{*}{$\begin{array}{l}\text { Resp } \\
\text { Pilihan }\end{array}$} & \multirow{2}{*}{\multicolumn{4}{|c|}{ UA }} & \multirow{2}{*}{\multicolumn{4}{|c|}{ Unesa }} & \multirow{2}{*}{\multicolumn{4}{|c|}{ ITS }} & \multirow{2}{*}{\multicolumn{4}{|c|}{ IAIN Sunan Ampel }} \\
\hline & & & & & & & & & & & & & & & & \\
\hline & U⿳亠丷厂 & Unesa & ITS & IAIN & UA & Unesa & ITS & IAIN & UA & Unesa & ITS & IAIN & UA & Unesa & ITS & IAIN \\
\hline 1 & 83 & 3 & 17 & 5 & 37 & 74 & 36 & 5 & 5 & 2 & 96 & 0 & 10 & 9 & 7 & 39 \\
\hline 2 & 13 & 22 & 62 & 4 & 61 & 24 & 36 & 8 & 84 & 8 & 3 & 2 & 14 & 25 & 14 & 8 \\
\hline 3 & 0 & 74 & 18 & 3 & 33 & 35 & 52 & 9 & 9 & 87 & 0 & 3 & 21 & 17 & 19 & 2 \\
\hline 4 & 5 & 2 & 4 & 89 & 4 & 2 & 11 & 113 & 1 & 2 & 0 & 94 & 16 & 10 & 21 & 12 \\
\hline \multicolumn{15}{|c|}{ asosiasi merek (kepercayaan) } & & \\
\hline Resp & \multicolumn{4}{|c|}{ UA } & \multicolumn{4}{|c|}{ Unesa } & \multicolumn{4}{|c|}{ ITS } & \multicolumn{4}{|c|}{ IAIN Sunan Ampel } \\
\hline Pilihan & $\mathrm{UA}$ & Unesa & ITS & IAIN & UA & Unesa & ITS & IAIN & UA & Unesa & ITS & IAIN & UA & Unesa & ITS & IAIN \\
\hline 1 & 74 & 2 & 25 & 6 & 33 & 61 & 47 & 4 & 5 & 0 & 94 & 0 & 19 & 5 & 14 & 29 \\
\hline 2 & 21 & 16 & 61 & 3 & 53 & 35 & 36 & 7 & 78 & 17 & 5 & 2 & 16 & 17 & 19 & 7 \\
\hline 3 & 2 & 81 & 10 & 9 & 41 & 38 & 46 & 9 & 15 & 81 & 0 & 2 & 12 & 27 & 18 & 3 \\
\hline 4 & 4 & 2 & 5 & 83 & 8 & 1 & 6 & 115 & 1 & 1 & 0 & 95 & 14 & 12 & 10 & 22 \\
\hline \multicolumn{15}{|c|}{ kesan kualitas (kualitas) } & & \\
\hline Resp & \multicolumn{4}{|c|}{ UA } & \multicolumn{4}{|c|}{ Unesa } & \multicolumn{4}{|c|}{ ITS } & \multicolumn{4}{|c|}{ IAIN Sum Ampel } \\
\hline Pilihan & $\mathrm{UA}$ & Unesa & ITS & IAIN & UA & Unesa & ITS & IAIN & UA & Unesa & ITS & IAIN & UA & Unesa & ITS & IAIN \\
\hline 1 & 57 & 2 & 44 & 5 & 49 & 30 & 66 & 5 & 6 & 0 & 95 & 0 & 28 & 4 & 22 & 14 \\
\hline 2 & 38 & 12 & 47 & 4 & 61 & 35 & 31 & 2 & 84 & 10 & 4 & 4 & 18 & 8 & 28 & 7 \\
\hline 3 & 1 & 86 & 6 & 5 & 18 & 70 & 36 & 8 & 7 & 89 & 0 & 1 & 9 & 38 & 5 & 7 \\
\hline 4 & 5 & 1 & 4 & 87 & 7 & 0 & 2 & 120 & 2 & 0 & 0 & 94 & 6 & 11 & 6 & 33 \\
\hline \multicolumn{15}{|c|}{$\frac{1}{2 \text { (dua) pilihan PTN }}$} & & \\
\hline Resp & \multicolumn{4}{|c|}{ UA } & \multicolumn{4}{|c|}{ Unesa } & \multicolumn{4}{|c|}{ ITS } & \multicolumn{4}{|c|}{ IAIN Sunan Ampel } \\
\hline Pilihan & $\mathrm{UA}$ & Unesa & ITS & IAIN & UA & Unesa & ITS & IAIN & UA & Unesa & ITS & IAIN & UA & Unesa & ITS & IAIN \\
\hline 1 & 85 & 0 & 16 & 0 & 36 & 68 & 31 & 0 & 4 & 0 & 95 & 0 & 9 & 9 & 8 & 35 \\
\hline 2 & 18 & 16 & 65 & 1 & 48 & 52 & 48 & 8 & 90 & 3 & 4 & 1 & 16 & 19 & 16 & 9 \\
\hline
\end{tabular}

Sumber: jawaban angket, diolah peneliti 
Tabel 3 menunjukkan responden memiliki top of mind pada kampusnya, sehingga membentuk kepercayaan terhadap kampusnya dalam memenuhi harapan mereka selama berkuliah. Namun ternyata tingkat kepercayaan responden IAIN menunjukkan dua pendapat. Hal tersebut dikarenakan adanya kenyataan terdapat mahasiswa IAIN yang masuk bukan karena keinginan atau passion yang dimiliki, namun merupakan suatu keterpaksaan atau pilihan terakhir. Kepercayaan tersebut tidak mempengaruhi kesan kualitas Responden ITS dan UA berkeyakinan kampusnya yang paling berkualitas. Berbeda dengan responden Unesa dan IAIN yang memilih kampus lain sebagai PTN yang paling berkualitas dan setuju menempatkan Unesa pada urutan ke-3 dan IAIN pada urutan ke-4. Responden menjadikan kampusnya sebagai pilihan utama bahkan juga menjadi pilihan kedua (responden Unesa).

Hasil pertanyaan tertutup melalui 34 item pertanyaan yang dianalisis menggunakan regresi linier berganda berdasarkan masing-masing PT sebagai berikut:

Tabel 4: hasil uji regresi

\begin{tabular}{|c|c|c|c|c|c|}
\hline variabel & regresi & UA & Unesa & ITS & IAIN \\
\hline konstanta & & $-0,224$ & 0,785 & 0,572 & 0,945 \\
\hline \multirow[t]{3}{*}{$\mathrm{X} 1$} & $\mathrm{~B}$ & 0,310 & 0,225 & 0,904 & 0,384 \\
\hline & $\mathrm{t}$ & $(3,060)$ & $(2,360)$ & $(6,197)$ & $(2,505)$ \\
\hline & $\operatorname{Sig}(p)$ & 0,003 & 0,020 & 0,000 & 0,016 \\
\hline \multirow[t]{3}{*}{$\mathrm{X} 2$} & $\mathrm{~B}$ & 0,016 & 0,110 & $-0,208$ & $-0,034$ \\
\hline & $\mathrm{t}$ & 0,123 & 1,111 & $-1,770$ & $-0,343$ \\
\hline & $\operatorname{Sig}(p)$ & 0,902 & 0,269 & 0,080 & 0,733 \\
\hline \multirow[t]{3}{*}{ X3 } & $\mathrm{B}$ & 0,822 & 0,473 & 0,199 & 0,383 \\
\hline & $\mathrm{t}$ & $(5,317)$ & $(4,273)$ & 1,963 & $(3,320)$ \\
\hline & $\operatorname{Sig}(p)$ & 0,000 & 0,000 & 0,053 & 0,002 \\
\hline \multicolumn{2}{|c|}{$\mathrm{F}$} & 22,432 & 18,077 & 14,731 & 13,450 \\
\hline \multicolumn{2}{|c|}{$\operatorname{Sig}(p)$} & 0,000 & 0,000 & 0,000 & 0,000 \\
\hline \multicolumn{2}{|c|}{ R square } & 0,425 & 0,293 & 0,332 & 0,447 \\
\hline \multicolumn{2}{|c|}{ adjusted $\mathrm{R}$ square } & 0,406 & 0,277 & 0,309 & 0,413 \\
\hline
\end{tabular}

Sumber: hasil pengujian SPSS, diolah peneliti

Pengaruh Kesadaran Merek terhadap Keputusan Memilih

Nilai kesadaran merek (X1) responden UA berada dibawah 0,05 sehingga disimpulkan berpengaruh signifikan. Pada pertanyaan terbuka responden menunjukkan kesadaran merek yang tinggi terhadap kampusnya. Hal tersebut tidak terlepas dari peran orang lain serta banyaknya responden berasal dari luar kota Surabaya dalam memberikan saran selama proses keputusan memilih tempat berkuliah. Sehingga responden UA mampu memilih PTN berdasarkan minat atau jurusan yang diinginkan. Tingkat pengenalan tersebut menunjukkan bahwa responden mampu mengenali UA (recognition), mengingat hingga mampu menggambarkan UA (recall), serta UA menjadi top of mind bagi responden yang memilih UA pada pilihan pertama atau mengenal UA sebelum melakukan proses keputusan memilih tempat berkuliah. 
Nilai signifikan kesadaran merek (X1) kurang dari 0,05 sehingga dapat disimpulkan bahwa $\mathrm{X} 1$ berpengaruh terhadap keputusan memilih. Hal tersebut ternyata disebabkan responden telah memiliki pengetahuan yang cukup tentang Unesa sehingga menjadi top of mind. Disamping itu responden memiliki kepercayaan diri yang tidak lepas dari kepentingan orang disekitarnya. Kepentingan ini lebih kepada persepsi bahwa Unesa itu murah, Unesa memiliki jurusan yang diinginkan responden, dan Unesa berada di Surabaya. Orang tua sering kali menjadi faktor utama dalam kepentingan tersebut, karena terkait biaya ataupun lokasi berkuliah mayoritas responden masih harus bergantung pada orang tua.

Nilai signifikan kesadaran merek (X1) berada di bawah 0,05 yang diartikan X1 mempengaruhi keputusan memilih. Responden ITS memiliki kesadaran yang paling tinggi diantara ketiga PTN lain. Penyebabnya sebagian besar responden yang tidak hanya berasal dari jawa timur hingga jawa barat. Indikasinya responden yang berasal dari luar Surabaya memiliki kesadaran yang tinggi terhadap ITS sehingga memiliki percaya diri untuk memutuskan memilih ITS sebagai tempat berkuliah. Bahkan responden ITS benar-benar telah mempersiapkan diri untuk bisa masuk ITS. Adapun responden yang ternyata memilih ITS karena jurusan yang dimiliki bukan karena keterkenalan ITS. Pendapat tersebut menunjukkan bahwa responden ITS memiliki kesadaran merek dalam memilih ITS sebagai tempat berkuliah.

Nilai signifikan kesadaran merek (X1) berada di bawah 0,05 yang diartikan X1 mempengaruhi keputusan memilih. Responden IAIN memiliki kesadaran merek yang tinggi terhadap IAIN namun tidak lebih tinggi dibandingkan kesadaran responden di ketiga PTN lain. Hal tersebut dikarenakan adanya pandangan khusus masyarakat terhadap IAIN yang berbasis agama islam. Tidak menutup kemungkinan adanya keinginan responden yang lebih terhadap menuntut ilmu (berkuliah) beserta mendalami agama islam bersamaan. Namun hal tersebut tidak disertai kepercayaan diri mereka dalam memutuskan memilih berkuliah di IAIN. Karena pada pertanyaan terbuka terkait pilihan PTN responden memilih PTN lain baik pada pilihan pertama maupun kedua. Responden lebih dipengaruhi oleh hal lain tanpa adanya kesadaran merek berkemungkinan lebih besar.

Hasil penelitian ini mendukung penelitian Wang et al (2008) yang menjelaskan "kesadaran merek memiliki pengaruh terhadap ke-putusan pembelian". Namun ber-tentangan dengan hasil penelitian pramosa (2012) yaitu kesadaran merek tidak mempengaruhi keputusan pembelian. Bahkan reputasi PT dalam memprediksi kesadaran merek, digunakan sebagai acuan menilai suatu PT atau merek PT untuk membuat keputusan memilih (Brewer dan Zhao, 2010). Sehingga dapat disimpulkan bahwa hasil penelitian ini sesuai dengan hipotesis pertama $\left(\mathrm{H}_{1}\right)$

\section{Pengaruh Asosiasi Merek terhadap Keputusan Memilih}

Nilai signifikan asosiasi merek (X2) lebih dari 0,05 menunjukkan tidak mempengaruhi keputusan memilih UA. Namun pada pertanyaan terbuka menunjukkan responden UA memiliki kepercayaan pada kampusnya. Asosiasi merek dalam penelitian ini diindikasikan melalui familiaritas, kesuksesan alumni, dan keunikan UA. Pengaruh yang lemah ini didukung pendapat responden yang lebih percaya bahwa kesuksesan alumni bergantung pada kemampuan individu. Pendapat tersebut mampu mencerminkan kesadaran responden bahwa tujuan berkuliah untuk mencari ilmu bukan mencari kerja, sehingga pendapat masyarakat yang menganggap bahwa "lulusan PTN paling mudah mencari kerja" tidak berlaku. Hal ini dikarenakan keunikan PTN tidak menyeluruh tapi pada jurusan atau prodi atau layanan 
tertentu. Familiaritas responden UA fokus pada jurusan yang diinginkan serta pendapat "yang penting masuk PTN" sehingga menimbulkan adanya pendapat "PTN di Surabaya cuma UA yang punya farmasi”.

Nilai signifikan asosiasi merek (X2) lebih dari 0,05 sehingga dapat disimpulkan bahwa X2 tidak berpengaruh terhadap keputusan memilih. Namun kenyataannya kepercayaan responden terhadap Unesa menimbulkan Unesa sebagai pilihan pertama dan kedua. Penyebab lemahnya pengaruh tersebut tidak lain suatu akibat dari rebranding yang belum melekat dibenak responden. Adapun sejarah Unesa yang dahulunya bernama IKIP Surabaya dan pada tahun 1999 berubah menjadi Unesa. Ternyata perubahan tersebut masih belum efektif sehingga menyebabkan paradigma IKIP di benak Unesa belum hilang. Hal tersebut sering kali membuat ilmu murni yang berada di Unesa belum mendapat kepercayaan penuh yang pada kenyataanya jurusan manajemen dan akuntansi memiliki anmeo yang paling besar. Sehingga familiaritas Unesa masih belum merata di benak responden. Pada pertanyaan terbuka Unesa menjadi pilihan kedua, hal ini mengindikasikan ketidakunikan Unesa karena memiliki beberapa fakultas atau jurusan yang juga dimiliki PTN lain yaitu fakultas ekonomi, fakultas ilmu sosial, fakultas teknik, fakultas mipa, dan fakultas bahasa. Namun hanya Unesa yang memiliki jurusan pendidikan di dalamnya. Hal tersebut menjadi pertimbangan responden untuk memilih Unesa menjadi pilihan utama.

ITS memiliki kepercayaan paling besar dari responden. Namun nilai signifikan asosiasi merek (X2) berada di atas 0,05 yang diartikan X2 tidak berpengaruh terhadap keputusan memilih. Ternyata hal tersebut tidak disebabkan oleh asosiasi kesuksesan alumni ataupun keunikan ITS namun lebih kepada prestasi yang dimiliki. Jaminan kesuksesan alumni karena menjadi alumni ITS sudah menjadi kejenuhan dibenak responden, karena responden lebih tertarik terhadap prestasi yang dimiliki atau akreditasi jurusan yang dimiliki. Teknik memang menjadi basis ITS berdampak pada kejenuhan tentang persepsi bahwa lulusan PTN akan mudah mencari kerja, sehingga asosiasi merek dalam penelitian ini tidak memiliki pengaruh terhadap keputusan memilih.

Nilai signifikan asosiasi merek (X2) berada di bawah 0,05 yang diartikan X2 mempengaruhi keputusan memilih. Kepercayaan responden IAIN terhadap kampusnya ternyata menunjukkan hasil ganda yaitu IAIN sebagai yang paling dipercaya dan yang paling kurang dipercaya. Penyebabnya dalam keputusan memilih IAIN responden cenderung memilih karena ilmu atau basis yang ditawarkan IAIN kepada responden yang juga tercermin pada berbagai fakultas berbahasa arab. Sedangkan pengaruh kesuksesan alumni, familiaritas, maupun keunikan IAIN bukan menjadi pertimbangan utama.

Sesuai dengan fenomena yang terjadi ternyata kepercayaan tidak dibangun melalui kemampuan lulusan PTN di dunia kerja maupun di masyarakat serta bukan pula melalui kemampuan PTN dalam menunjuk-kan keunggulannya. Bahkan res-ponden percaya bahwa kesuksesan didapat dari "kemampuan individu" bukan almamater. Ternyata dalam asosiasi merek, mahasiswa lebih mempertimbangkan harga dan kualitas yang dimiliki PTN sebagai bentuk keterjaminan layanan pen-didikan tinggi yang diinginkan. Sehingga hasil penelitian ini tidak mendukung penelitian Paramosa (2012) dan Ergin et al (2006) yaitu "Terdapat pengaruh positif asosiasi merek terhadap keputusan pembelian" atau dapat dikatakan tidak sesuai dengan hipotesis pertama $\left(\mathrm{H}_{1}\right)$.

Pengaruh Kesan Kualitas terhadap Keputusan Memilih 
Nilai signifikan kesan kualitas (X3) kurang dari 0,05 artinya mempengaruhi keputusan memilih UA. Responden UA berpendapat kampusnya memiliki kualitas yang baik dengan adanya prodi unggulan di bidang kesehatan. Hal tersebut sebagai bentuk spesifikasi UA dalam memberikan kepercayaan responden tentang kualitasnya. UA yang juga memiliki fasilitas student center serta kerjasama dan IO sebagai bentuk kepedulian UA untuk perkembangan dan peningkatan kemampuan responden dalam mengembangkan softskillnya. Hal tersebut membuat responden merasa bahwa biaya kuliah yang ditetapkan telah sesuai dengan kualitas yang diberikan. Namun masih ada beberapa kekecewaan terkait pelayanan karyawan maupun keamanan.

Nilai signifikan kesan kualitas (X3) kurang dari 0,05 sehingga dapat disimpulkan bahwa X3 berpengaruh terhadap keputusan memilih. Responden Unesa tidak berpendapat bahwa Unesa memiliki kualitas paling baik diantara ketiga PTN lain. Hal tersebut sesuai dengan paradigma responden yang masih menganggap "Unesa sebagai IKIP", sehingga responden memilih Unesa bahkan pada pilihan pertama maupun kedua. Realitanya Unesa memiliki biaya pendidikan yang paling murah dibandingkan dengan ketiga PTN lain. Unesa juga memiliki pusat bahasa yang telah tersertifiaksi, perpusatakaan, dan fasilitas olahraga terlengkap (Putri, 2009) sehingga tidak sedikit responden yang mempertimbangkan Unesa dalam hal fasilitas.

Responden memiliki kesan kualitas yang baik dibanding ketiga PTN lain. Namun ternyata nilai signifikan X3 berada diatas 0,05 yang diartikan tidak berpengaruh. Disamping itu nilai koefisien menunjukkan tanda positif sehingga kesan kualitas berpengaruh tidak signifikan. Adapun penyebab yang mungkin adalah terkait prestasi yang dimiliki ITS, sehingga berbagai pernyataan tentang kesan kualitas bukan lagi menjadi pertimbangan utama justru kesadaran merek yang membawa prestasi tersebut yang menjadi pengaruh terbesar dalam keputusan memilih ITS. Bahkan responden ITS tidak ragu untuk menjawab pernyataan terkait kompetensi ITS karena responden ITS percaya bahwa masing-masing PTN memiliki kualitasnya masing-masing. Realitanya, kampus ITS sukolilo memiliki berbagai fasilitas yang mendukung kualitasnya seperti lapangan olahraga disetiap fakultas, maupun sarana bagi pertukaran pelajar ke luar negeri. Sehingga kesan kualitas dapat berpengaruh positif walaupun bukan menjadi pertimbangan utama responden.

Nilai signifikan kesan kualitas (X3) berada di bawah 0,05, yang berarti kesan kualitas dapat mempengaruhi keputusan memilih berkuliah di IAIN. Kesan kualitas memiliki pengaruh yang paling besar dikarenakan adanya proses rebranding dan pengembangan fasilitas IAIN sehingga responden memiliki pertimbangan yang lebih besar terhadap kualitas. Berbagai hal telah dirancang sehingga memunculkan berbagai fasilitas IAIN yang ter-rebranding ke dalam bahasa inggris. Namun tidak memunculkan suatu kepercayaan diri responden sehingga kesan kualitas IAIN menjadi yang terendah diantara ketiga PTN lain. Hal ini yang menyebabkan dalam memilih IAIN responden tidak terlalu besar dalam mempertimbangkan, namun justru terdapat faktor lain yang memungkinkan dalam keputusan memilih.

Hasil penelitian ini mendukung penelitian Paramosa (2012) dan Yee et al (2011) yang menjelaskan "Adanya pengaruh persepsi kualitas terhadap keputusan pembelian". Lebih lanjut diteliti oleh Angell et al (2008) yang menghasilkan "faktor kualitas layanan yang memiliki pengaruh besar adalah akademis dan kemitraan dengan industri". Penelitian tersebut juga memiliki pendapat yang sama dari responden dalam penelitian ini bahwa PTN di Surabaya memiliki pengajar yang ahli, program yang bereputasi, dan kompetensi yang baik. Selain itu PTN di Surabaya juga memiliki pusat layanan karir serta memiliki fasilitas dan 
informasi pertukaran pelajar. Sehingga dapat disimpulkan bahwa hasil penelitian ini sesuai dengan hipotesis pertama $\left(\mathrm{H}_{1}\right)$

Keputusan memilih terkait city branding Surabaya

Kerjasama pemerintah kota Surabaya dengan berbagai kota besar di luar negeri tersebut telah mendapatkan manfaatnya baik disektor ekonomi/ perdagangan maupun sosial budaya. Kota Seattle, Kochi, dan Busan merupakan kota yang memiliki pelabuhan besar sehingga Surabaya mendapat kesempatan bekerjasama dalam perdagangan ekspor. Namun konsep tersebut tidak menjadi perhatian utama bagi responden luar kota Surabaya. Responden melihat Surabaya sebagai pusat perdagangan convenience good yang selanjutnya dijadikan peluang untuk melakukan usaha dagang sambil berkuliah dengan melihat nilai manfaat kerjasama tersebut. Adapun pendapat responden yang mendukung, "saya ingin berkarya di Surabaya dengan berbagai peluang yang ada".

Disisi lain penataan infrastruktur kota Surabaya sebagai salah satu upaya kebijakan branding, sehingga responden menganggap bahwa dalam memilih PTN juga mempertimbangkan infrastruktur. Responden cenderung mempertimbangkan kelancaran transportasi sebagai fasilitas pendukung. Pemahaman tersebut lebih dijelaskan secara umum Surabaya memiliki kompleks industri, sebagai pusat kegiatan di Jatim, sebagai kota dengan sosio kultur, serta berbagai program pembangunan kota (mis: frontage road).

Disamping itu ada beberapa responden keempat PTN di Surabaya yang tidak menjadikan city branding sebagi top of mind ketika melakukan proses evaluasi alternative. Keputusan memilih lokasi berkuliah lebih dipengaruhi oleh kepentingan minat belajar itu sendiri. Hal tersebut didukung oleh pernyataan "yang penting negeri dan sesuai dengan jurusan yang saya minati". Reponden memutuskan memilih PTN lebih mementingkan branding dari PTN bukan branding Surabaya dengan dukungan saran dari orang lain (orang tua, guru, kakak kelas, maupun PTN expo). Bahkan ada beberapa responden yang punya keinginan kembali ke kota asalnya setelah lulus kuliah. Sehingga keragaman responden dalam memaknai city branding Surabaya dikaitkan dengan lokasi tempat berkuliah juga dipengaruhi oleh ekspektasi responden setelah kuliah.

\section{SIMPULAN}

Dari hasil pembahasan dapat disimpulkan sebagai berikut:

1. Kesadaran merek dan kesan kualitas berpengaruh secara ppositif terhadap keputusan memilih PTN di Surabaya, namun asosiasi merek memiliki pengaruh yang berbeda dimana UA dan Unesa berpengaruh secara positif sedangkan ITS dan IAIN berpengaruh negatif.

2. Responden kurang mempertimbangkan city branding Surabaya. Namun selama proses kuliah responden mendapatkan kesan city branding Surabaya walaupun belum memahami sepenuhnya.

Adapun peneliti menyarankan sebagai berikut:

1. Perguruan tinggi harus selalu melakukan evaluasi terhadap kualitas layanannya.

2. Program studi harus melakukan komunikasi atas capaian kinerjanya (prestasi, seminar, program lainnya). 
3. Komunikasi city branding harap menjangkau tingkat unit/lembaga pendidikan, sehingga tidak hanya menjadi kesan namun juga dapat menjadi pemahaman.

4. Peneliti selanjutnya:

a. Jika melakukan penelitian pada responden mahasiswa sebelum tindak lanjut penyebaran angket diharapkan untuk melakukan wawancara terlebih dahulu agar mendapatkan jawaban yang konkrit.

b. Meneliti lebih lanjut terkait harga (biaya pendidikan) dan WOM (Word Of Mouth) dikarenakan faktor tersebut sangat mempengaruhi mahasiswa dalam memeilih PTN di Surabaya.

\section{DAFTAR REFERENSI}

Aaker, David. 1997. Manajemen Ekuitas Merek, Jakarta: Spektrum.

Alma, Buchari. 2005. Pemasaran Stratejik Jasa Pendidikan, Bandung: Alfabeta.

Alma, Buchari. 2008. Manajemen Corporate Dan Strategi Pemasaran Jasa Pendidikan, Bandung: UPI

Angell Et Al. 2008. Service Quality In Postgraduate Education. Quality Assurance In Education 16/3: 236-254.

Brewer Dan Zhao. 2010. The Impact Of A Pathway College On Reputation And Brand Awareness For Its Affiliated University In Sydney. International Journal Of Educational Management 24/1: 34-47

Bunzel, David L. 2007. Universities Sell Their Brands. Journal Of Product And Brand Management 16/2: 152-153.

Chapleo, Chris. 2010. What Defines "Successful" University Brands?. International Journal Of Public Sector 23/2: 169-183.

Dikti .2010. Perkembangan Jumlah Perguran Tinggi Tahun 2010, Reported by Dikti.

Endwiasri, Ayunita. 2010. Pengaruh Brand Equity terhadap keputusan konsumen memilih masakapai penerbangan garuda Indonesia, Surakarta: Universitas Sebelas Maret.

Engel Et Al. 2002. Perilaku Konsumen Jilid 1 Edisi Enam, Jakarta: Binarupa Aksara

Ergin Et Al. 2006. The Effect Of Brand Associations: A Field Study On Turkish Consumers. International Business And Economics Research Journal 5/8: 65-74

Ghozali, Imam. 2012. Aplikasi Analisis Multivariate dengan Program IBM SPSS 2.0, Semarang: Badan Penerbit Universitas Diponegoro.

Juanda. 2010. Peranan Pendidikan Formal Dalam Proses Pembudayaan. Lentera Pendidikan, 13/1: $1-15$

Keller, Kevin. 2003. Strategic Brand Management, Prentice Hall: University of California. 
Kotler, Phillip Dan Gary Armstrong. 2005. Marketing: An Introduction, New Jersey: Pearson

Kotler, Phillip Dan Keven L. Keller. 2009. Manajemen Pemasaran Jilid 1 Edisi 12, Jakarta: Indeks

Kotler, Phillip Dan Keven L. Keller. 2009. Manajemen Pemasaran Jilid 2 Edisi 12, Jakarta: Indeks

Lovelock Dan Wright. 2007. Manajemen Pemasaran Jasa, Jakarta: Indeks

Lupiyoadi, Rambat dan Hamdani. 2009. Manajemen Pemasaran Jasa Edisi 2, Jakarta: Salemba Empat.

Magnadi, Rizal Hari dan Farida Indriani. 2011. Peran Perguruan Tinggi dalam Membangun "City Branding" yang Berkelanjutan: Sebuah Upaya untuk Mendorong Pertumbuhan Perekonomian Daerah. Prosiding SNaPP2011: Sosial, Ekonomi, dan Humaniora 2/1: 281-289.

MasterCard. 2012 .Kesadaran Masyarakat akan Pendidikan Makin Tinggi, reported by kampus okezone.

Moogan, Yvonne J. 2010. Can A Higher Education's Marketing Strategy Improve The Student-Institution Match?. International Journal Of Educational Management 25/6: 570-589.

Muntean Et Al. 2009. The Brand: One Of The University's Most Valuable Asset. Annales Universitas Apulensis Series Oeconomica 11/2:1066-1071

Malhotra, Naresh K. 2009. Riset Pemasaran Pendekatan Terapan edisi keempat jilid 1, Jakarta: PT. Indeks.

Paramosa, Maisie L. 2012. Analisis Faktor-Faktor Pembentuk Ekuitas Merek Terhadap Keputusan Pembelian Jasa Hotel Narita Surabaya. (online) (http://studentjournal.petra.ac.id/index.php/manajemen-perhotelan/article/view/206, diakses pada 25 April 2013).

Parasuraman, Berry, dan Zeithaml. 1991. Refinement and reassessment of the servqual scale. Journal of retailing, 67/4: 420-450.

Rahman, 2008. Analisis Brand Association Dalam Meningkatkan Ekuitas Merek Bank Riau Kepri Pekan Baru, reported by repository unri.

Santoso, Singgih. 2004. Mengolah Data Statistik Secara Professional, Jakarta: PT. Elex Media Komputindo Kelompok Gramedia

Santoso, Singgih Dan Fandy Tjiptono. 2004. Riset Pemasaran Konsep Dan Aplikasi Dengan SPSS, Jakarta: PT. Elex Media Komputindo Kelompok Gramedia.

Snmptn 2013. 2013. Daftar Perguruan Tinggi Di Indonesia, reported by snmptn administration. 
Ria Astuti Andrayani

Sri Setyo Iriani
Jurnal Manajemen Bisnis Indonesia Vol. 2, Nomor 1, Oct 2014

So et al. 2010. When experience matters: building and measuring hotel brand equity: the customers' perspective. International journal of contemporary hospitality management, 22/5: 589-608.

Solomon, Michael R. 2013. Consumer Behaviour: Buying, Having, And Being Tenth Edition, USA: Pearson Education.

Sumarwan, Ujang. 2011. Perilaku Konsumen Edisi Kedua. Bogor: Ghalia Indonesia.

Surabaya. 2011. Sister City. Reported by Surabaya administration online.

Temporal, 2001. Marketing Strategy in Asia. Jakarta: Binarupa Aksara.

Tjiptono, Fandy. 2005. Brand Management and Strategy, Yogyakarta: Penerbit Andi

Tjiptono, Fandy. 2008. Strategi Pemasaran Edisi III, Yogyakarta: Penerbit Andi

Wang Et Al. 2008. Global Brand Equity Model: Combining Customer-Based With ProductMarket Outcome Approaches. Journal Of Product \& Brand Management 17/5: 305-316

Wijaya, David. 2008. Pemasaran Jasa Pendidikan Sebagai Upaya Untuk Meningkatkan Daya Saing Sekolah. Jurnal Pendidikan Penabur 1/11: 42-56

Wishman (2009). Internal Branding: A University's Most Valuable Intangible Asset. Journal Of Product And Brand Management 18/5: 367-370

Yee et al. 2011. Consumers' Perceived Quality, Perceived Value And Perceived Risk Towards Purchase Decision On Automobile. Ameican Journal Of Economics And Business Administration 3/1: 45-57 